\title{
ANALYSIS OF EDUCATIONAL PROGRAMS IN THE FIELD OF "GEODESY AND REMOTE SENSING"
}

\author{
Nadezhda Khakhulina', Valery Barinov ${ }^{2}$ \\ Julia Netrebina $^{3}$, Larisa Maslikhova ${ }^{4}$
}

\author{
${ }^{1}$ Candidate of Technical Sciences, Associate Professor, Voronezh State Technical \\ University, 20 years of October street, 84,Voronezh, Russia, E-mail: hahulina@mail.ru \\ ${ }^{2}$ Doctor of Technical Sciences, Associate Professor, Voronezh State Technical University, 20 \\ years of October street, 84,Voronezh, Russia, E-mail: kafedravgasu@yandex.ru \\ ${ }^{3}$ Candidate of geographical Sciences, Associate Professor, Voronezh State Technical University, \\ 20 years of October street, 84,Voronezh, Russia, E-mail: juliya_net@mail.ru \\ ${ }^{4}$ Candidate of History, Associate Professor, Voronezh State Technical University, 20 years of \\ October street, 84,Voronezh, Russia, E-mail: lim29-78@mail.ru
}

\begin{abstract}
Russia's participation in the Bologna Process began in 2003, but major changes have begun to take place in the last decade. The article examines a phased process of changing educational programs on the example of the direction "Geodesy and Remote Sensing" of two levels of education: bachelor's and master's degrees. Highlighted structural changes in programs implemented on the basis of Federal State Educational Standards for 2009, 2015, 2020. The analysis of educational blocks and modules in terms of the independent participation of organizations that implement educational programs in the formation of competencies and content of programs. Comparison of the content of the directions in the field of geodesy in different countries of the world. General trends are highlighted and differences are identified.
\end{abstract}

Keywords: Bologna process, bachelor's, master's, educational program, Federal State Educational Standard

\section{I.INTRODUCTION}

Geodesy - the science of measuring on the earth's surface is one of the oldest on the planet. With the development of cities, countries and civilizations, the issues of measuring territories were of great importance. Today this scientific discipline has a large list of areas of application: the construction of residential buildings, various buildings and unique structures, observation of defomation of structures, geodynamics and even the study of other planets. At the present stage in the arsenal of surveyors there are unique and effective technologies, devices and tools that distinguish the work of today's surveyor from the surveyor of the last century and even the beginning of the 21 st century. The tasks of surveyors in different countries of the world are the same, but the training of specialists in this area is different. The purpose of this study is to compare educational programs (EP) in different countries of the world. In Russia, educational programs are formed on the basis of the Federal State Educational Standards (FSES). In accordance with the Bollon system of education in Russia, there is a two-tier system of higher education (bachelor's and master's degrees, then, unlike other countries, there is a candidate of science and a doctorate). The volume of credit units of educational programs is determined in accordance with the principles of the Bologna process and is 240 credit units for the undergraduate program and 120 for the master's program. Over the past ten years, the Federal state educational standards for training bachelors in the field of "Geodesy and Remote Sensing" have changed three times: 2009 (as amended in 2011) [1], 2015 [2] and 2020 [3], for the 
preparation of masters at the same time $[4,5,6]$. The requirement for organizations implementing basic educational programs, which consists in the presence of a license issued by an authorized federal executive body, remains unchanged. Also, the general requirement of all standards is that in order to receive state diplomas, it is necessary to undergo state accreditation on the territory of the Russian Federation.

\section{METHODOLOGY}

The research is theoretical. In comparing educational programs, an analytical method was used; in the course of the study, educational programs were considered according to their components, content and structure. The paper traces the hierarchy of Federal State Educational Standards and compares these documents over a ten-year period. The general points are highlighted, the similarity in the approach to the educational process is established and the differences are determined. Based on the comparison results, conclusions are drawn.

\section{DISCUSSION}

Geodesy as a tool is used in many professional spheres of the economy of the country of any state. The profession of a surveyor will always be relevant and in demand. The scope of its application is wide, and the toolkit is not limited to optical, laser and digital devices. In total, 12 universities in Russia are training in Geodesy and Remote Sensing in November 2020, including VSTU - Voronezh State Technical University; in the direction of "Applied Geodesy" - 14 universities. Beginning in 2018, VSTU and other universities in Russia began to introduce such disciplines as "Project activity" and "Technological entrepreneurship". The methods of project planning and management have shown their relevance and effectiveness all over the world. In his Address to the Federal Assembly in 2018, the President of the Russian Federation V.V. Putin spoke about the role of the state in the modern world, which is determined primarily by people, the conditions for development, self-realization, and creativity of each person. Referring to the experience of implementing large-scale programs and social projects, the President proposed another large-scale project - updating the urban environment, which should be based on the widespread introduction of innovative technologies. This project includes new economic and social prospects for people, a modern living environment, for cultural and civic initiatives, for small businesses and startups. It is the involvement of people in the affairs of the country and civic activity, as well as cultural, moral and spiritual values, according to the President, that make Russians a single people capable of achieving great goals [7].

In the Federal Republic of Germany, responsibility for the education system is divided between the Federation and the Länder. The scope of the federal government's responsibilities in the field of education is defined in the Basic Law (Grundgesetz) [8]. If the Basic Law does not give the Federation legislative powers, the Länder have the power to make laws. In the education system, this applies to the school sector, the higher education sector, adult education and continuing education. The administration of the education system in these areas is almost entirely under the jurisdiction of the Länder. [9]. Many technical schools and universities in Germany provide undergraduate and graduate programs in Geodesy and Geoinformatics. Undergraduate studies include modules in natural sciences and specialized subjects: Students are trained in modules in natural sciences, mathematics and specialized subjects: engineering mathematics; experimental physics; geological sciences; software collection of geodata; statistical data; geodetic calculations; geodetic measuring instruments; fundamentals of the global positioning system (GPS); the engineering geodesy; geoinformation and cartography; space planning; rules for the management of space and real estate; photogrammetry and remote sensing (from space); leveling calculations; astronomical, physical and mathematical geodesy; basics of positioning and navigation; interference holographic analysis method; image processing; computer graphics and visualization; right; enterprise economics and national economy. In German universities, practice sometimes takes an entire semester. [10]

The Master's program "Geodesy and Geoinformatics" is characterized by linking geodesy to the areas of research and the content of teaching in the field of geoinformatics. The Master's program "Geodesy and Geoinformatics" lasts four semesters and includes a total of 120 credit units, which in terms of labor intensity corresponds to the Russian EP. During the first semester, students must select their modules from a given base directory. This semester is important as it aims to bring students to a common standard and create a foundation for science education throughout the program. In the 2nd and 3rd semesters, students must choose one area of specialization (main subject) from the following thematic blocks: Geoinformation technologies; Space geodesy and navigation; Engineering survey and estimation theory; Computer vision and remote sensing. You can get this specialty in almost all universities in Germany: Munich, Berlin, Dresden, Hamburg and many others. The French education system is characterized by strong central government involvement in the organization and financing of education. The French education system is 
regulated by the Department of National Education, Higher Education and Research. [eleven]. In France, training in the specialty "Surveyor" is registered in the National Directory of Professional Certificates (RNCP), level III of the French nomenclature (certificate level +2 ) [12]. Classes in the bachelor's degree focus on the following disciplines: topography; GPS; photogrammetry and remote sensing; IT development; GIS, cartography; maths; Social sciencies.

In the French universities' master's degree in geodesy-related specialties, training in remote sensing and spatial data analysis is provided. The training lasts one academic year and is divided into: theoretical and practical training, consisting of 460 hours of classes, from September to March, which takes place in educational institutions; Internship in companies or laboratories from 4 to 6 months, from April to September. In other countries of the world, when studying in specialties related to geodetic orientation, the situation is generally similar in terms of studying disciplines with the countries discussed above and Russia [8-14]. The analysis of EP in different countries showed that the main disciplines that form a sought-after specialist in the field of geodesy are: topography, photogrammetry and remote sensing, satellite systems and positioning technologies, GIS technologies.

\section{RESULTS}

For a bachelor's degree, the standard term for mastering OEP, including postgraduate leave for full-time education, is 4 years and 240 credit units. For a master's degree, the standard term for mastering the OEP for full-time education, including postgraduate leave, is 2 years and 120 credit units. FSES defines the types of professional activity of graduates: research and scientific-pedagogical; production and technological; organizational and managerial; design and survey. It should be noted here that in 2020 the Federal State Educational Standard formulates this point somewhat differently, not the types of professional activity, but the types of tasks of professional activity. An organization implementing an educational program has the right to choose one or more types of tasks based on the chosen profile or focus of the program. The main difference between the standards [1] [2] and [3] lies in the requirements for the results of the development of programs. In [1] and [2] it is quite clearly spelled out which general cultural (OC), general professional (OPK) and professional (PC) competencies should be formed in a graduate as a result of mastering EP. PCs were clearly related to the types of professional activity. With this approach, the competencies formed by the Federal State Educational Standards determine the choice of disciplines that should provide these competencies. In [3], instead of OK, universal competences (CC) appear, the OPK is also defined, and the right to formulate PC is given to organizations independently on the basis of professional standards corresponding to the professional activities of graduates. This approach gives the organization the right to choose those professional competencies that are most in demand on the labor market. The requirements for the structure of the OP have also changed. The comparison is presented in the table.

In the standard [1], the disciplines of the basic part of blocks B1, B2 and B3 were defined. For block 1 (1. Philosophy 2. History 3. Foreign language 4. Microeconomics 5. Management and marketing); for block 2 (1. Mathematics 2. Mathematical methods of processing and analysis of geospatial data on a computer 3 . Informatics 4. Physics 5. Ecology 6. Geomorphology with the basics of geology); for block 3 (1. Introduction to the specialty 2 . Geodesy 3 . Higher geodesy 4 . Space geodesy 5 . The theory of mathematical processing of measurements 6 . Satellite systems and positioning technologies 7 . Remote sensing and photogrammetry 8. General cartography 9. Metrology, standardization and certification 10. Geographic information systems and technologies 11. Life safety); as can be seen from the table, block 4 is reserved for physical culture. The EP section of block B5 is compulsory and is a type of training sessions directly focused on the professional and practical training of students. Specific types of practices are determined by the EP of the university. Final state certification includes the defense of the final qualifying work. The state exam is introduced at the discretion of the university. In the document [2], the disciplines (modules) related to the basic part of the undergraduate program are mandatory for the student to master, which he is mastering. The organization determines the set of disciplines (modules) related to the basic part of the program independently in the amount established by the Federal State Educational Standard. This document defines a small part of the disciplines (philosophy, history, foreign language, life safety and physical education), which are included in the basic part of block 1. Disciplines (modules) related to the variable part of the program, and practices form the focus of the EP and are determined by the organization independently. 


\section{Table}

Structure of programs [1] [2] and [3]

\begin{tabular}{|c|c|c|c|c|c|c|}
\hline \multicolumn{2}{|c|}{ [1] } & \multicolumn{2}{|c|}{ [2] } & \multicolumn{3}{|c|}{ [3] } \\
\hline \multirow{3}{*}{$\begin{array}{c}\text { Block } 1 \\
\text { Humanitarian } \\
\text {, social and } \\
\text { economic } \\
\text { cycle }\end{array}$} & & \multirow{4}{*}{$\begin{array}{l}\text { Block } 1 \\
\text { Disciplines } \\
\text { (modules) }\end{array}$} & & \multirow{4}{*}{\multicolumn{2}{|c|}{$\begin{array}{c}\text { Block } 1 \\
\text { Disciplines } \\
\text { (modules) }\end{array}$}} & mandatory part \\
\hline & & & & & & \\
\hline & Variable part & & $\begin{array}{l}\text { Variable } \\
\text { part }\end{array}$ & & & $\begin{array}{l}\text { mandatory part } \\
\text { part formed by }\end{array}$ \\
\hline \multirow{2}{*}{$\begin{array}{c}\text { Block } 2 \\
\text { Mathematical } \\
\text { and natural } \\
\text { science cycle }\end{array}$} & Basic part & & & & & $\begin{array}{l}\text { participants in } \\
\text { educational } \\
\text { relations }\end{array}$ \\
\hline & Variable part & \multirow{2}{*}{$\begin{array}{l}\text { Block } 2 \\
\text { Practices. } \\
\text { Variable } \\
\text { part }\end{array}$} & Training & \multirow{5}{*}{$\begin{array}{c}\text { Block } 2 \\
\text { Practice } \\
\text { s. }\end{array}$} & \multirow{2}{*}{$\begin{array}{l}\text { Trainin } \\
\mathrm{g}\end{array}$} & mandatory part \\
\hline \multirow[t]{2}{*}{$\begin{array}{c}\text { Block } 3 \\
\text { Professional } \\
\text { cycle }\end{array}$} & $\begin{array}{l}\text { Basic (general } \\
\text { professional) } \\
\text { part }\end{array}$ & & Production & & & $\begin{array}{l}\text { mandatory part } \\
\text { part formed by } \\
\text { participants in } \\
\text { educational } \\
\text { relations }\end{array}$ \\
\hline & Variable part & \multirow{2}{*}{$\begin{array}{c}\text { Block } 3 \\
\text { State final } \\
\text { certification }\end{array}$} & \multirow[b]{2}{*}{ Basic part } & & \multirow{3}{*}{$\begin{array}{l}\text { Product } \\
\text { ion }\end{array}$} & \multirow{2}{*}{$\begin{array}{l}\text { mandatory part } \\
\text { part formed by } \\
\text { participants in } \\
\text { educational } \\
\text { relations }\end{array}$} \\
\hline Block 4 & $\begin{array}{l}\text { Physical } \\
\text { education }\end{array}$ & & & & & \\
\hline Block 5. & $\begin{array}{l}\text { Educational and } \\
\text { industrial } \\
\text { practice }\end{array}$ & & & & & \\
\hline Block 6 & $\begin{array}{l}\text { Final state } \\
\text { certification }\end{array}$ & & & Blo & & $\begin{array}{l}\text { State final } \\
\text { certification }\end{array}$ \\
\hline
\end{tabular}

The types of educational (practice for obtaining primary professional skills and abilities, including primary skills and abilities of research activities; performing practice) and production (research work; technological) practices are determined. Ways of conducting industrial practice: stationary; exit. Also compulsory is prediploma practice, which is carried out to complete the final qualifying work. The university chooses the types of practices depending on the chosen type of activity, which the EP is focused on. Also, the organization has the right to choose other types of practices independently. State final state certification is included in block B. 3 and includes defense and preparation for the defense of the final qualifying work. Also, this block may include passing the state exam at the discretion of the university. FSES of higher education [3] represents a great freedom of the organization, which implements EP in the choice of disciplines, since the independent formulation of the PC determines their composition. Compulsory disciplines (modules) of block B.1 are philosophy, history, foreign language, life safety and disciplines in physical culture and sports. Block 2 includes educational (introductory, technological, design, operational practice and research work) and production (technological, design, operational practice and research work) practice. In accordance with the requirements [3], it is possible to choose at least one practice from the production and educational types of practices. As in [1] and [2], the final stage is the state final certification, in [3] it is included in block 3 and includes a state examination (at the discretion of the organization) and preparation for the defense procedure and defense of the final qualifying work.

Practice is an integral part of any learning process, in practice the knowledge gained in the course of theoretical training is consolidated and expanded, the competencies that were mastered in previous disciplines are applied and honed. The internship allows you to acquire the necessary practical skills in your specialty in a production environment; master the advanced methods of technology and labor. The scope of practices defined in [1] [2] and [3] varied. For undergraduate studies in [1] [2] and [3], the volume of practice varied, respectively, $12.5 \%-14.5 \% ; 13 \%-26 \% ; 12.5 \%-29.5 \%$ of the total OP. As you can see, the lower limit remains unchanged, but the upper limit increases. The university independently decides on the approval of 
the scope of practice within each program being implemented. For a master's degree, the situation is somewhat different. In [1], the volume of practice was in the range of $40-48 \%$; in [2] from 37 to $42.5 \%$; in [3] is currently in the range from 33 to $42.5 \%$. In master's programs, the largest volume of practice fell on the period 2009-2015, during the subsequent period the volume of practice remained practically unchanged.

\section{CONCLUSION}

The analysis of educational programs [1] [2] and [3] showed that the process of integration with the Bologna process in the Russian Federation is intensifying. At the beginning of the educational reform, the composition and content of the EP were almost completely guided by the Federal State Educational Programs, a mandatory minimum was introduced containing a rigid list of disciplines and reporting methods, which universities were prohibited from violating [1]. The standards controlled the volume and content of all items. In educational programs based on [2], up to about half of the compulsory disciplines are established, the rest remains with the organizations that implement EP. The new standards [3] provide for the practical, completely independent definition of disciplines (modules) and practices. The transition of EP to a competency-based approach has been carried out, and in accordance with the latest standard, PCs are formulated by the organizations themselves, thereby attracting a larger number of employers. [15-20]

\section{REFERENCE LIST}

1. Professional Education in the field of training 120100 Geodesy and remote sensing ((qualification (degree) "bachelor") // URL: http://fgosvo.ru/uploadfiles/fgos/12/20111115143033.pdf (on Russian)

2. Federal state educational standard of higher education in the field of training 03/21/03 Geodesy and remote sensing (bachelor's level) // URL: http://fgosvo.ru/uploadfiles/fgosvob/210303.pdf (in Russian)

3. Federal state educational standard of higher education - bachelor's degree in the direction of training 03/21/03 Geodesy and remote sensing // URL: http://fgosvo.ru/uploadfiles/FGOS\%20VO\%203++/Bak/21.03.03.pdf ( in Russian)

4. Federal state educational standard of higher professional education in the direction of training 120100 Geodesy and remote sensing (qualification (degree) "Master") // URL: http://fgosvo.ru/uploadfiles/fgos/39/20110321092535.pdf (in Russian )

5. Federal state educational standard of higher education in the field of training 03/21/03 Geodesy and remote sensing (master's level) // URL: http://fgosvo.ru/uploadfiles/fgosvom/210403.pdf (in Russian)

6. Federal State Educational Standard of Higher Education - Master's Degree in the field of training 03.21.03 Geodesy and Remote Sensing // URL: http://fgosvo.ru/uploadfiles/FGOS\%20VO\%203++/Mag/210403_M_3_22082020.pdf (in Russian )

7. Kudinova O.S., Skulmovskaya L.G. (2018) PROJECT ACTIVITY AT THE UNIVERSITY AS THE BASIS OF INNOVATIONS // Modern problems of science and education. - 2018. - No. 4.; URL: http://www.science-education.ru/ru/article/view?id=27928 (date accessed: 14.12.2020).) (In Russian)

8. Basic Law for the Federal Republic of Germany of May 23, 1949 (BGBI. 1949,1, p. $1 \mathrm{ff}$.), Perm. changed by law of March 28, 2019 (Federal Law Gazette I 2019.11, p. 404 f.) (German)

9. Germany Overview. National Specificities of the Education System// URL: https://eacea.ec.europa.eu/national-policies/eurydice/content/germany_en (in English)

10.Munich Technical University // URL: http://euni.ru/vuzy/germaniya/bavaria/muenchen/tu-muenchen (in Russian)

11.France Overview.Key features of the Education System // URL: https://eacea.ec.europa.eu/nationalpolicies/eurydice/content/france_en (in English)

12. Minister of Higher Education, Research and Innovation // URL: https://www.enseignementuprecherche.gouv.fr/ 9 in French)

13.Geodesy and Geomatics Engineering // URL: https://www.unb.ca/gradstudies/programs/gge.html (in English)

14. Higher education in Turkey // URL: https://abroadz.com/vysshee-obrazovanie-v-turczii/ (in Russian) 
15. Khakhulina N.B., Popov B.A., Netrebina Yu.S., Kharitonova T.B. (2020) About design methods in education. В сборнике: 7th INTERNATIONAL CONFERENCE ON EDUCATION AND SOCIAL SCIENCES. Abstracts \& Proceedings. 2020. C. 102-107. (in English)

16. Khakhulina N.B., Trukhina N.I., Ivanov B. (2020) The role of competence approach in formation of functional literacy of learners. В сборнике: 7th INTERNATIONAL CONFERENCE ON EDUCATION AND SOCIAL SCIENCES. Abstracts \& Proceedings. 2020. C. 128-133. (in English)

17. Maslikhova L., Khakhulina N., Barinov V., Radugina O. (2020) Experience in developing the educational program "archaeological research in construction". В сборнике: 7th International Conference on Education and Education of Social Sciences. Abstracts \& Proceedings. E-Publication. 2020. C. 170174. (in English)

18. Khakhulina N.B. (2019) Environmental engineering in educational and design activities. Khakhulina N.B., Ivanov B.I. Environmental models and technologies (regional aspect). No. 1 (8). Pp. 26-. (in Russian).

19. The Bologna Process and the European Higher Education Area // https://ec.europa.eu/education/policies/higher-education/bologna-process-and-european-highereducation-area_en (in English)

20.Altbach Ph.G., Reisberg L., Rumbley L.E. (2009) Trends in Global Higher Education: Tracking an Academic Revolution. A Report Prepared for the UNESCO 2009 World Conference on Higher Education. Paris, UNESCO. 247 p. (in English) 